Article

\title{
Sustainable Banking: The Role of Multilateral Development Banks as Norm Entrepreneurs
}

\author{
Alvaro Mendez ${ }^{1,2, *(1)}$ and David Patrick Houghton ${ }^{3}$ \\ 1 ESIC Business \& Marketing School, 28224 Madrid, Spain \\ 2 Global South Unit at LSE IDEAS \& Department of International Relations, London School of Economics and \\ Political Science, London WC2A 2AE, UK \\ 3 National Security Affairs, U.S. Naval War College, Newport, RI 02481-1207, USA; \\ David.Houghton@usnwc.edu \\ * Correspondence: a.mendez@lse.ac.uk
}

Received: 29 December 2019; Accepted: 24 January 2020; Published: 29 January 2020

check for updates

\begin{abstract}
This article explores the role of multilateral development banks (MDBs) in originating norms of sustainable banking that have attracted and supported green private finance, a role not widely known in the management literature. Any prospect of achieving the United Nations (UN) Sustainable Development Goals by 2030 presupposes mobilizing the estimated US $\$ 23.3$ trillion currently locked-up in risk-averse private savings to bridge the gap between developing countries' demand for capital and the current global financial architecture's capacity to supply it. The three biggest obstacles to sustainable banking identified by the authors are discussed: (1) The uncertain bankability of projects; (2) non-transparency in tracking sustainable capital flows; and (3) no universal mechanism capable of making matches between green investment supply and demand; and what MDBs have actually done to overcome these roadblocks, and might do in future, is also discussed. Seen through the lens of "applied constructivism", MDBs are revealed to be norm entrepreneurs proactive since at least the 1970s in socially constructing most of the basic norms and practices of sustainable banking which the private sector relies on or is now striving to take up. MDBs are typically the first "port of call" for international governmental organizations (IGOs) and civil society organizations wishing to establish a sustainable financial framework for development; and are the likeliest political agents to pioneer sustainable banking in future. MDBs would do well to develop an awareness of the methods of Constructivism, which they have actually been unwittingly using, to empower themselves to meet the challenges of the 21st century.
\end{abstract}

Keywords: sustainable banking; multilateral development banks (MDBs); norm entrepreneurs; constructivism; sustainable development goals (SDGs); international development; commercial banks

\section{Introduction}

Sustainable development is a notion that has cut across international civil society, from international governmental organizations (IGOs), non-governmental organizations (NGOs), media and academia, even to the commercial banking sector via "sustainable banking". The United Nations has defined sustainable development in terms of seventeen "sustainable development goals" (SDGs), setting 2030 as the deadline for achieving them. However, progress is behind schedule, and a consensus has emerged that finance and investment on an unprecedented scale is the solution [1]. Experts estimate that global annual capital investment of US\$5-7 trillion will be needed to attain the Goals by 2030. In the developing world alone, the figure is US\$3.3-4.5 trillion, with the midpoint at US\$3.9 trillion. As actual current investment is merely US\$1.4 trillion, a massive gap of US\$2.5 trillion per year subsists [2]. To bridge this chasm, coordinated mobilization of private capital is necessary, according to a joint 
report by 7 multilateral development banks (MDBs) [3]. As is detailed below, the MDBs have been the financial institutions that have pioneered most of the working norms of sustainable banking, pace conventional wisdom, and the potential and importance of their ability to engage private banks is measured by the chasm. Their report's title, From Billions to Trillions [3], expressing the scale of investment needed to fund the SDGs on time, and identifying MDBs' lack of access to world savings as the main obstacle, has become synonymous with the needed mobilization [4]. More than enough savings exists to meet the demand: the latest estimate of annual global private savings was US\$23.3 trillion [5], nine times the developing-world shortfall. The commercial banking industry has access to this ocean of capital, in theory, yet by itself has too little control of risks to make a match with the developing economies' range of opportunities for capital investment [6].

The cornerstone of development finance strategy so far has focused on increasing funds via foreign aid or Official Development Assistance (ODA) [7], but this is not enough [8,9]. We contend that the multilateral development banks and the commercial banks need each other to reach truly sustainable finance for the SDGs; neither can go it alone. Vital to success is a systemic partnership between the MDBs, with their risk-dampening "political" resources, and the commercial banks, with their access to private savings which, in this age of negative interest rates and stock market bubbles, desperately seeks lower risks yet higher returns on investment (ROI). MDBs and commercial banks would make a brilliant match in their own right if they would but exploit each other's strengths while compensating for each other's weaknesses. In this regard, however, it is essential to understand that MDBs must take the lead. Of the two classes of partners, only they have the unregulated, international agency (or freedom of action) to innovate norms of sustainable finance. They are therefore the best-positioned to act as norm entrepreneurs in the social construction of sustainable banking.

The management literature on sustainable banking contains little on the critical role of MDBs in socially constructing the policy framework within which commercial banking and its sustainability has been assessed by scholars. The idea of organizational entrepreneurship is as crucial to the study of sustainable banking as to any other economic endeavor [10], but it is not always appreciated that non-profit IGOs might be capable of it (much less in the lead). This article contributes to the field by surveying in particular the critical ways and means that MDBs have brought and can bring to bear on the problems specifically of commercial financiers sincerely interested in reaching sustainability, and facilitating others to do so as well (viz., SDGs). The article is structured as follows. The next, second section defines the key terms of this article, especially MDBs and norm entrepreneurship. The third section takes up the question of sustainable banking in practice by analyzing three important issues: (1) Sustainable banking in contemporary perspective; (2) sustainable banking and sustainable development; and (3) what bars commercial banks going the whole route to sustainability. The fourth section covers what MDBs offer commercial banks wishing to make good their sustainability duties and undertakings. The last, fifth section concludes with a brief discussion and remarks.

\section{Key Terms and Definitions}

Sustainable banking. The concept of sustainable banking is dynamic and evolving. Historically, it began with "social banking" or philanthropic community development. This became "ethical banking" by building non-profit ethics principles into business operations. "Green banking" followed, which took ecology into account. "Sustainable banking" situates the foregoing in an environmental, social, and governance (ESG) framework promoting sustainable development [11]. A sustainable bank internalizes both ESG systems and ethical conduct policies. It recognizes multiple stakeholders who represent sustainability themes [12]; viz., its management's transparency to the public; its financial products' import for green risks; and the impact of the acts of IGOs and MDBs for its operations [13]. We would simply add, from the economist's angle, that a sustainable bank will routinely undertake, whether or not in exchange for valuable consideration (e.g., buyer goodwill, political risk minimization) or not, due diligence to trace its own market externalities, i.e., effects on third parties, and their affordably 
maximal mitigation in case of a negative. This abstraction features the market, implying that sustainable investment by multitudes of profit-seekers can exist on a large scale.

Multilateral development banks. MDBs are IGOs set up by agreement between three or more states to fund otherwise infeasible socioeconomic development projects [14]. They are banks but they differ significantly from commercial ones: They do not maximize ROI, take no deposits, pay no taxes, distribute no dividends, and are self-regulating independently of central banks and national governments. They do provide loans, invest equity, guarantee against risk, and donate technical cooperation. MDBs represent the priority of capital mobilization over concessional aid. Their charters assign them a complementary role: They may not overreach private lenders who provide funds on reasonable terms. MDBs can take sovereign guarantees unavailable to commercial banks, and can offer longer maturities and lower interest rates. They are expected to implement their member states' policy mandates, whilst helping to shape policy reforms by borrowers [15]. MDBs did not always take sustainability duly into account [16], yet they were among the first to face environmental issues [15]. With few exceptions their charters reflect current sustainability norms [17]. MDBs have exerted broad policy influence on all stakeholders through their dialogues with national governments and their role as a catalyst of private investment. Their solutions have influenced how every phase and scale of ecological problem is conceived. Their tough trade-offs between development and ESG show how to instantiate abstract paradigms of sustainable development [15]. As MDBs make part of global finance, it is incorrect to reduce sustainable banking to nothing but a phase of commercial banking.

Norm entrepreneurship. There is a special type of agency that consists of some persons convincing a critical mass of others to abandon old norms of appropriate behavior for new ones [18]. The term's originator, legal scholar Cass Sunstein, defined norm entrepreneurs as "people interested in changing social norms" [19] (p. 909). Such persons have also been called "transnational moral entrepreneurs" [20] (p. 482); "policy entrepreneurs" [21] (p.71); and "international rule innovators" [22] (p.85). Norms of human behavior do not fall out of the sky or grow on trees; they are purposely constructed by persons exercising free will ("agents") with often headstrong ideas about what behavior is appropriate. Norm entrepreneurs are originators or early catalysts whose disruptive acts build momentum toward contemplation of new templates of collective action [23], by adverting to issues, or even creating them, using discourses that name, shame, reinterpret, and/or dramatize and problematize the incumbent norms. If successful, the revisionary issue-framings find widespread sympathy in the underlying population, and get adopted as a new perspective on reality [18]. Such agents may mobilize public opinion in both their home countries and abroad; found like-minded movements in foreign countries; and aim for end-purposes transcendent to their own national interests [20]. Other scholars have understood these exceptional persons as "meaning architects" who pinpoint social meanings for reformation, and find ways of effecting this [24].

MDBs as norm entrepreneurs, as seen through Constructivism. Social scientists are apt to understand sustainable banking in Constructivist terms, as "whatever bankers and their stakeholders make of it" [25]. Constructivism in social science theorizes the "co-constitutedness" of (collective) agency and social structures, chief among which are "norms": beliefs whose existence depends on being shared by all. Belief in the value of paper money or in the safety of obeying traffic signals cannot survive unless everyone believes it. Because our norms do not occur in nature but have to be "socially constructed", we inhabit a social world the meaning of which is what we collectively choose to make of it [25-28]. Constructivists note paradoxes in this state of affairs, such as that popular belief in democracy is what stabilizes it in the teeth of its manifest failures; and practitioners should note that enlisting self-fulfilling beliefs in the cause of revising existing norms is fraught with unintended consequences: Widespread belief in the Clash of Civilizations [29] may be hastening the very outcome which the idea's originator propounded it to prevent. Norms in transition are prone to the influence of unknown and unforeseeable factors which will, if they can, impact the outcome.

Now, sustainable banking is just this sort of "social construct", that is, the (institutional) outcome of collective political agency. But in its current state it is inchoate- "under construction" as it were-and 
so, politically contested. Researchers then receive mixed signals about what the stakeholders and shareholders of banking are making of it. A fascinating window is opened onto social construction in action, exposing its traceable processes and epitomizing what has been called Konstruktpolitik [27].

Konstruktpolitik. Also known as "applied constructivism", this term is patterned after Realpolitik; hence, a school of thought in international politics that uses the social theory of Constructivism as a guide to clearer thinking about effective public-political practices. It is Constructivism in prescriptive mode, solving real problems after being informed by studying past or present cases of effectual action through social construction. Policy makers can learn to construct norms and institutions in pursuit of ends like sustainable banking on a bedrock foundation of self-fulfilling beliefs and expectations about others' imminent or remote acts [30]—shared beliefs that support reciprocating behavior; e.g., a green traffic light means "go", but a red light means "stop" for everybody. Without access to other minds, we must infer what they believe. The more individuals who believe that Everybody Believes whatever it may be, the likelier that everybody will end up believing it, even though few would have believed it unless and until (nearly) all did. Applied constructivism rests on the stabilization of such reciprocating beliefs. "Enough" people believing them is a tipping-point that, when reached, will constitute their practical validity. To conform to what you are convinced others are convinced is a norm is to contribute to creating the norm $a b$ ovo.

Constructivist analysis reveals that it is multilateral development banks who have emerged as the chief entrepreneurial agents and venues for constructing and disseminating new ideas and norms in the world of sustainable development. MDBs are not equally entrepreneurial, however; the World Bank, that iconic MDB, is identified by scholars as the undisputed arbiter of development norms [31], even before the concept of sustainability had made any impact on development finance. Its staff became the "entrepreneurial hegemon" within the expert development community [32]; for example, though not the first to conceive the importance of poverty alleviation, it leveraged its unparalleled resources of money and cachet to normalize it, as long ago as the 1970s, as the approach to development. It did not hesitate to exploit its lending conditionality to enforce and reinforce this agenda. Not only the other MDBs but also nation-states and international agencies have emulated the World Bank paradigm. Perhaps nearly as important is that its representative multilateral configuration (like that of all MDBs) serves to legitimize its norms [21].

\section{Sustainable Banking in Contemporary Perspective}

The story of sustainable banking's evolution in the contemporary age is important so as to evince its Constructivist nature and origin for the sheer sake of knowledge. But it will also serve to orient us to the likely future, and even to educate and guide our participation in the constructive process itself. It is intended that such a perspective will also inform research in the management field.

Contemporary sustainable banking was socially constructed under the influence of larger forces of structure and agency. The structural ones were autonomous norm-setting IGOs, especially the UN. It hosted the first Conference on the Human Environment (UNCHE) in 1968, and then the United Nations Environment Programme (UNEP) in 1972. These all tied demands from the global South for structural changes in the global economy to environmental issues, and this became the political basis of the sustainable development idea [33]. The other, agential (i.e., "grassroots") factors were civil society's demands for investments consistent with social justice values originating in the protest movements of the 1960s. The first mutual fund for socially responsible investing (SRI), the Pax World Fund, was set up in 1971 to nudge corporations toward benchmarks of corporate social responsibility (CSR) [11,34]. All these factors operated as intra- and extra-market constraints on the agency of corporations, including commercial banks and other for-profit financial institutions [35], which problematized poverty and underdevelopment as by-products of market failure, and conceived the general solution as a managed integration of the poor countries into global capital (not merely consumer) markets [36].

These ideas have percolated very slowly into commercial banking; indeed, sustainable banking was not even a viable option before the 1980s; nothing but bankability factored into a business 
model [37]. But in 1980 the Brandt Commission (BC) issued a Report proposing ecological impact assessments, and appealing to MDBs to take up the practice so as to bring a green perspective to development planning [38], and to help developing countries access private capital within this framework by extraordinary devices like giving their guarantees to commercial banks and leveraging their own capital to ease lending terms [39]. In 1987 the World Commission on Environment and Development (WCED) issued Our Common Future ("The Brundtland Report"), urging the need of private, public and public-private partnerships [15]; calling on MDBs to be responsible for promoting sustainability generally [40]. The Report is credited with introducing into SRI the term "sustainable development" [11], yet criticized for lacking a clear operational definition of sustainability, the fuzziness of which invited its misuse as greenwash [41-43]. Both Reports sparked key debates on banking practices and inspired a spate of international forums which institutionalized inter-governmental cooperation: the Global Environmental Facility (GEF) in 1991, to sponsor partnerships between states, IGOs, NGOs, and the private sector, focused on ecological threats [44]; the UN Environmental Programme Financial Initiative (UNEP FI) in 1992, a partnership with international financiers to mobilize private capital for sustainable development, its annual UNEP FI Global Roundtables in Geneva discussing the topic of "greening financial markets" [45]; and the "Earth Summit", or UN Conference on the Environment and Development (UNCED) in 1992, calling for massive increases in development aid and MDB co-financing to help developing countries transition to sustainable growth [15,46].

At this point the commercial banking sector perceived a profit opportunity: to innovate financial products in step with sustainable development [11]. The business-as-usual obsession with short-term gain undervalues natural ecology; discounts the future disproportionately; and relies on accounting methods blind to environmental risks. The multinational commercial banks began to inquire how financial markets might support "eco-efficiency" [47]. The net result was the Dow Jones Sustainability Index (DJSI) in 1999, the first global index to measure corporate sustainability $[11,48]$. The public sector was not resting on its oars. The UN Millennium Declaration in September 2000 [49] foreran the Millennium Development Goals (MDGs); eight goals for developing countries to aim to achieve by 2015 (e.g., "cut poverty in half") which only came out in 2001 after intense pulling and hauling within the UN itself $[50,51]$. Opinion was divided between the supporters who claimed the MDGs were bold but achievable [52], and the critics who rejoined that they were beyond the capacity of ordinary human enterprise [53]. And they were not in fact achieved, not for lack of resources but for inability to mobilize them [54]. But pent-up capital is the norm (though hope springs eternal). The MDGs were superseded in 2015 by the Sustainable Development Goals (SDGs), seventeen even more ambitious targets that address development challenges ranging from climate change to poverty and hunger [55]. They are already behind schedule and likely headed for failure. The Secretary General of UNCTAD recently asseverated that capital outlay on an unprecedented scale and level of coordination will be needed to achieve them by 2030 [1].

\subsection{Sustainable Development and Sustainable Banking}

Meanwhile, the Brundtland Report was spawning myriad versions of sustainable development. Yet this is the crucial construct: The very constitution of sustainable banking hinges on what it is that one is socially constructing. The lack of a clear shared meaning means it is "essentially contestable". The ongoing contest is itself a critical dialogue that constitutes the persuasiveness and versatility of a dynamically evolving idea [56]; it allows "stakeholders" - third parties not privy to a commercial transaction, whose interests are affected nevertheless-to adapt meaning to standpoint, from the global to the local and across sectors and institutions. The swarms of stakeholders urging banks means that a broad spectrum of civil society agency is deeply interested in how finance might be made more sustainable [13].

To understand what is at stake, one must ask, what is to be sustained? The US National Academy of Sciences' Board on Sustainable Development identified three categories of sustainables: "Nature" 
(viz., earth's biodiversity and ecosystems), "Life Support" (viz., what mankind needs from nature: e.g., resource goods and ecosystem "services"), and "Community" (viz., human cultures and social groups and the unique places they create and inhabit) [57]. Banking which is not destructive of these things is sustainable [56]. In a similar vein, scholars agree that financiers ought to take account of their own ESG impacts [58-60]. One influential norm of sustainability interprets account-taking literally, consisting of exact reforms to corporate accountancy known as the Triple Bottom Line, which subjects corporations to social and ecological accountabilities as well as financial [61].

The most influential of all sustainable development norms are the SDGs, of which the last one, SDG17 (addressing the means of implementing the other sixteen), deserves mention for the strategic direction it gives in relating sustainable development to sustainable banking; in sum: "Strengthen the means of implementation and revitalize the Global Partnership for Sustainable Development" [55] (p.14). This Partnership was laid out by the precursor MDGs [49]. Target 12 of MDG8 directed, “Develop further an open, rule-based, predictable, non-discriminatory trading and financial system" [50] (p. 58). As that was not even approximated [62], the successor SDGs have troubled to define SDG17 in 19 specifics, of which the two set forth in Table 1 best pertain to the present purpose [55] (pp. 26-27):

Table 1. Sustainable development goal (SDG)17-Targets 17.3 and 17.17.

\begin{tabular}{lc}
\hline Target & Specification \\
\hline 17.3 & Mobilize additional financial resources for developing countries from multiple sources. \\
\hline 17.17 & $\begin{array}{r}\text { Encourage and promote effective public, public-private and civil society partnerships, } \\
\text { building on the experience and resourcing strategies of partnerships. }\end{array}$ \\
\hline
\end{tabular}

SDG17 specifically envisions partnership between the public and private sector for collaborative finance. The crux of sustainable banking is here; however, organizing large multi-stakeholder groups depends critically on "sophisticated implementation structures" [63] (p. 193). It is contended that private partners collaborating with multilateral development banks are better positioned to take up the challenges of implementation than either acting alone.

\subsection{What Bars Commercial Banks Going the Whole Route to Sustainability?}

What does the record say about commercial banks' performance to date? Elkington complains that corporate accountants and reporting consultants have captured his epoch-making accountancy-accountability device, the Triple Bottom Line [64]. Profit targets are all single-mindedly pursued, but people and planet targets rarely [64,65]. Constraints on commercial agency prevent the private sector to implement sustainability by itself. Agency constraints may be external (imposed by social structures such as market competition, consumer sovereignty, and the rules of accounting); or internal (i.e., cognitive psychology limitations like indifference to ecological concerns). External constraints can interact with internal (e.g., biases toward in-group cohesion and out-group conflict-exacting bank officers' loyalties to their bank). Constraints are absolute (e.g., the imperative for banks to avoid insolvency at all costs); partial (e.g., the difficulty of finding bankable projects, even if known to be "out there"); or probabilistic (e.g., banks are likely to use sustainability as greenwash so long as it is cost-effective). Given so many disincentives, private agency in favor of green finance never ceases to impress.

We proceed to review three interrelated fronts on which commercial banks are still struggling to achieve sustainability: Uncertain bankability of projects; non-transparency in tracking sustainable capital flows; and the want of a universal mechanism that can "match-make" green investment supply and demand. It is necessary to present these fronts in panorama so that the reader may have a background good enough for a contextual understanding of the scope of the problems. Section 4 considers what MDBs have done and are likely to contribute to the mobilization of private capital (commercial banks in particular) toward meeting the world's development needs. 


\subsubsection{The Uncertain Bankability of Sustainable Projects}

Whatever disagreements may exist over the definition of "bankability" [66], the bottom line is that without the collateral resources to support implementation, no project will be financed, no matter how legally and technically feasible $[67,68]$. Banks cannot afford to lend money at sub-par rates of return. "Financial engineering" is the art of identifying all of the significant project risks, then writing contracts to allocate them [69]. Bankability rides on the project and its owner: the project's positive net present value plus the owner's cash flow to service the debt. Cash flow is assessed within the project's actual, counterfactually defined boundaries: What would be left without the project? Reckoning up a future, less the project, relies on present "best estimates" exposed to refutation by unforeseen events; so, net cash flow may be indeterminate. Feasibility studies often fail because of this [70]. Affordable, clean energy projects, for instance, demand enormous upfront capital but repay slowly, making long-term finance costly over the project lifetime. Private investors demand at least 10-15\% ROI, but clean energy cannot deliver a risk-adjusted return that high. If climate change is factored in, the difficulties mount higher still [71,72].

The transaction costs of quality feasibility studies are significant, but cannot reduce inaccuracy to insignificance. Sustainability entails foreseeing a more broadly conceived, longer-term future than business as usual, which exacts resources of time and money that commercial actors can rarely afford, especially given that elaborate preliminaries may net zero return if feasibility proves nil. Other factors also cause complications: Developing countries may lack administrative capacity to usher projects through the pipeline or model finance; governments cannot make the funding commitments or provide guarantees to mitigate risk. Weak state capacity makes sustainability costlier to private capital [71]. Path-dependency on yesterday's technology makes even efficient changes costly, and the risk of competitors siphoning off future cash flows taxes the willingness and patience of private capital [73]. The Basel III liquidity regulations requiring banks to hold more reserves to offset long-term, illiquid assets shrinks the pool of bankable projects [74], which in turn inhibits MDBs investing in otherwise sustainable projects if their scale calls for supplementary private capital.

The SDGs would be interesting to banks if it were not so hard to unlock US $\$ 12$ trillion in private capital before 2030 [75]; even so, the industry is not unaware that the SDGs reflect the global systemic risks which will challenge business and society in a foreseeable future [76]. What makes sustainable banking doubtful is just the sheer time lag between today's expected return on investment and tomorrow's sustainability (a lag made worse by the 2008 credit crunch). Bridging such a lag means bridging the knowledge gap about the probable future of projects in situ. This is a market externality that depends so often on local third parties standing outside contractual arrangements. Commercial banks are hard put to handle market externalities that cannot be reflected in ordinary market pricing mechanisms. This is the key takeaway.

\subsubsection{Lack of Transparency in Tracking Sustainable Finance}

Financiers and their stakeholders cannot work toward the same goals without a common definition of them [77]. The ongoing contestation of sustainability hinders agreement on norms that can assure all sides which activities are truly sustainable. A master cipher is needed to decode sustainability and harmonize the swarm of methodologies. The industry's laudable initiatives have all devolved into chaos: Since 1997 the Global Reporting Initiative (GRI) has striven to standardize impacts on sustainability [78]; the Sustainability Accounting Standards Board (SASB), and the Carbon Disclosure Project's (CDP) benchmarks compete against it. The need for one rational, consistent reporting format is urgent, according to the head of the World Business Council for Sustainable Development (WBCSD); the conflicting private initiatives require so many surveys that it is "driving the industry crazy" [79]. Rival standards-setters, though sharing a common goal, stultify each other's endeavors with their unwillingness to collaborate and converge.

In 2015 the G20, concerned about the mess, took the initiative of a Task Force on Climate-related Financial Disclosures (TCFD), to quantify the sustainability risks of current commercial activities [80]. 
Its completion made 2017 the first year that private companies could report key performance indicators within a common format [81]. Bankers' support for TCFD is critical due to their strategic position as gatekeepers who enable commercial activities by finance $[82,83]$. The first response was net positive: 38 banks signed-on in 2017, raising hopes that ESG criteria had become commercially integral at last [81]. But then the numbers slumped: 29 pledged in 2018 but only 9 in 2019. One-third of the top 75 banks by assets demurred [82]. The 76 in support held $40 \%$ of total global banking assets, but just 39 (holding 24\%) have actually used the TCFD format [82,84]. If banks procrastinate sustainability, mounting stakeholder pressure will eventually motivate governments to intervene [85]. At the TCFD Summit in October 2019, the Governor of the Bank of England let on that the United Kingdom (UK) and European Union (EU) were both planning to make TCFD disclosure mandatory [86]. Heightened scrutiny implies a higher risk of liability in future for failure to disclose [87].

Comparable reporting is necessary but will not be sufficient if its information is not transparent in the sense of instantly intelligible, because itself standardized. Taxonomies are empirical tools for organizing vast reams of data retrievably [88], by type-casting similarities between objects hierarchically. Elemental likenesses are recognized and grouped into populations (taxa; e.g., species), then nested under more abstract categories (supertaxa; e.g., genus, phylum). Anything can then be cross-compared to anything on multiple levels of analysis simultaneously [88]. By classifying economic activities, not entities on the capital-markets, one taxonomy can specify what proportion of any entity's business is contributing to sustainable goals [89].

Stakeholders have long demanded taxonomies [90,91]. Eight central banks responded by setting up the Network for Greening the Financial System (NGFS) at the 2017 One Planet Summit in Paris, which has enlisted 42 central banks in less than two years. It published its first report in 2019 on three key functions of taxonomies: to (1) identify, assess and manage financial institutions' environmental risks; (2) better understand risk differentials as between types of assets; and (3) mobilize private capital for green investment [92]. The European Commission is creating such a taxonomy for the EU. Its Technical Expert Group (TEG) on Sustainable Finance, convened in 2018 [93], published its Taxonomy Technical Report in 2019, recommending that banks, in making lending decisions, should collect activity classifications, criteria, metrics, and thresholds from borrowers [94]. Commercial banks are on board: 130 of them in 49 countries holding more than US\$47 trillion in assets used the UNEP FI to launch the Principles for Responsible Banking that align their business strategies with the SDGs [95].

\subsubsection{The Need for a Systematic Matchmaking Facility}

Evidence from the global South shows that a few successful instances of matchmaking can cause a self-reinforcing chain reaction of new and repeat investment, as most investors base their decisions on information from other investors [96]. Many of the most important players in banking rue the lack of a matchmaking capacity. The Vice-Chairman of Citigroup recently remarked that if US\$3 trillion more a year must be mobilized to fulfill the SDGs, then a matchmaking facility, integral to the global capital markets and capable of scaling up to that level, is needed. It is not there yet [97].

This is being excogitated in experiments featuring local intermediaries, "investment facilitators", who know how to go between their local markets and international finance. These are the possessors of the reliable local knowledge that private capital is looking for, who can catalyze bankable opportunities; which tend to be small and medium-sized enterprises invisible to global banks [96]. Governmental facilities have been there on the ground for some time, trying to invite the global North in [98]. Norway has had a Business Matchmaking Programme under NORAD since 1995; Holland its Programme for Cooperation with Emerging Markets; Germany the Public-private Partnership project under (GTZ); Denmark a Private Sector Development program under DANIDA [99]. However, so far, these all lack the scalability deemed necessary by Citigroup.

Sustainable matchmaking is no longer confined to government ministries. Private initiatives are starting up to cater to investors seeking participation in green finance. Online investment platforms exemplify the trend, particularly crowdfunding, which already supports small-scale projects [100], 
and succeeds with EU renewable energy projects [101]. But it is a high-risk model; crowdfunds seem incapable of managing the risks to which the developing world will expose them. Other initiatives include the Green and Sustainable Hub [102]. But these are haphazard, uncoordinated reactions; better would be a comprehensive, scalable system, an "umbrella facility" for green financing deals.

The UK is trying to catalyze private finance by its 2019 Green Finance Strategy, launched by its Department for Business, Energy, and Industrial Strategy (BEIS). It has invested $£ 20$ million into a Clean Growth venture-capital fund to attract matching funds that might jump-start a private equity market [103]. UN Secretary General Guterres has set up the Global Investors for Sustainable Development Alliance (GISD), convoking 30 financial, manufacturing and technology leaders who may be willing to take responsibility for matching investors with opportunities for sustainable development [104], to pursue the UN's 2030 Agenda for Sustainable Development [105].

\section{Multilateral Development Banks (MDBs) and Sustainable Banking}

Flagship vehicles of conspicuous development aside, the actuality is, multilateral development banks have been the most forward-looking and proactive players in the arena of sustainable finance. Their agency in pioneering the social construction of practices for the whole industry is noteworthy in itself, and has lain behind many if not most relevant new institutionalizations of norms. It is just as likely to shape the future of sustainable banking. That said, candor exacts acknowledgement that there is much to merit criticism in the record which the MDBs of the world have compiled of missed opportunities and outright failures.

Critics sigh that MDBs have become beholden to their AAA credit ratings, which cramps optimal use of MDB balance sheets for achieving development goals, and slashes loans available to borrowers just when their hardships are peaking [106]; that the proliferation of MDBs causes wasteful duplication [17]; that rivalry between MDBs (not to be confused with market competition) on matters like policy advice, pricing, and modalities of finance may detrimentally impact the overall MDB system [107]; that MDBs' ever more politically reformist agendas misallocate resources to ills that MDBs are neither strategically nor operationally built to solve [108]. Reformers have recommended that MDBs ought to (1) reformulate their business model to identify (so as to alter) state and non-state actors' incentives in favor of providing global public goods; (2) collaborate amongst themselves to reallocate tasks and responsibilities according to the subsidiarity principle; (3) rethink their ways of operating in "fragile social and political contexts", reinterpreting non-interference so as not to preclude activities that may be vital to good governance and peace; (4) transition from a graduation to a gradation protocol to reflect the country context rather than the lending category only, rethinking capital adequacy accordingly; (5) reform their internal operations to give more scope to their clients' priorities and preferences; and (6) concentrate on cutting their often overlooked but far from trivial transaction costs for recipients, the better to leverage MDBs' comparative advantage [109]. If this article has accentuated the positive, it is only because the overall gestalt of the situation of sustainable development, and the role of private capital therein, is such that the leading role of MDBs is the best (possibly the only) way forward.

When all is said and done, MDBs' joint efforts are one of the best ways to approach sustainable banking issues [110]. In addition to the advances they have made already, what they may do in future is even more important to evaluate. The current unsettled state of affairs makes for an ideal case study of Konstruktpolitik, where the agency of norm entrepreneurs is "caught in the act" of contesting the new ways of doing business, which no one can yet discern the full dimensions of. It is nonetheless foreseeable in principle what MDBs are in a position to accomplish. In what follows, the actual accomplishments are reviewed, with a reevaluation of what they are poised to do but are not yet doing. The key to understanding is that MDBs have been the entrepreneurs making the IGOs' abstract development goals actually believable-by convincing "enough" participants that the new norms pioneered by the MDBs in sustainable development and finance are "already normal". In this, 
empirical evidence is adduced that the abstract principles discussed in previous sections have had material realizations by MDBs.

\subsection{MDBs' Pioneering Entrepreneurship}

It was MDBs that pioneered the now widely accepted norm of using sustainability criteria in lending decisions; for example, the European Bank for Reconstruction and Development (EBRD), which first brought ESG principles into its terms of reference in 1990. Most other MDBs have emulated EBRD [111]. In this sense, MDBs were thirteen years ahead of the Equator Principles (EPs) issued in 2003, themselves based on the lending criteria of the World Bank's private sector arm, the International Finance Corporation (IFC) [112]. The EPs furnished a ten-principled framework guiding project finance to an assessment of ecological and social as well as economic risks, and setting some minimum standards for mitigating them, which pledge lenders to withhold loans from borrowers who fail to comply [113]. As of December 2019, 101 financial institutions in 38 countries were observant [114]. Thus, MDBs' essential contribution to the adoption and implementation of the principles and procedures of sustainable development cannot be in dispute [115].

A recent IMF study used a large sample of developing countries to estimate the impact of MDBs on mobilization of private capital for sustainable development from 1993 to 2017. A significant effect was found, both direct and indirect. The number of deals increased, as did the total size of bank inflows and the number of lending banks. The average maturity of syndicated loans also lengthened. The economic effects were sizable, implying that MBDs could play an important role in mobilizing private capital to achieve the SDGs [116]. Development projects with huge potential catalytic impact may still be infeasible due not to unsound planning, but to public-sector fiscal restrictions. They can be made feasible by non-traditional financing with private investors via loan guarantees, equity investments, project bonds, or loan syndications. MDBs were originally chartered to make traditional loans to public-sector bodies. Retooling their practices can be frustrated by shareholder resistance or by their own organizational path-dependency. A new MDB such as the Asian Infrastructure Investment Bank (AIIB) has a better chance at norm entrepreneurship by constructing organizational structures, policies and cultures suitable to more sophisticated financing options $[117,118]$. This is facilitated by absorbing the lessons of MDBs with long private-sector experience; e.g., World Bank, EBRD, CAF [119], and translating them into what is an economic statecraft initiative alternative to the Western paradigm, and incidentally aimed at supporting Beijing in international politics [120].

\subsection{MDBs' Solutions and Enhancements to Sustainable Banking}

For decades MDBs have been proactively soliciting private participation in sustainable projects, and are in the throes of constructing new norms for public-private partnerships (PPP); especially so-called "blended finance", a platform for PPPs in which MDBs provide concessional loans as the basis for "crowding-in" private investors by de-risking their participation. MDBs possess, or can procure more easily than commercial bankers, detailed knowledge of the local social and economic situation. If only this kind of knowledge could be "coded" into a universally intelligible format, it would exert a transformative effect on private bankability assessments. MDBs have advanced such transparency by pioneering the compilation of taxonomies, and are better situated than commercial banks to demand transparency of local governments. MDBs have or are poised to develop the capacity to make matches between private capital supply and local demand in cases and places where ordinary capital markets are incompetent.

Indeed, MDBs' potential to mobilize private finance lies largely untapped. They are vital to the SDGs' plethora of stakeholders [121], to lead the transition from an aid transfer to a capital mobilization model [122] in innovating intermediations between local needs and global finance [123] which are conducive to social and ecological capital formation. MDBs know they must do more to unlock world savings. At the UN Secretary General's Climate Action Summit 2019 the world's biggest MDBs issued a High Level MDB Statement committing them to raise US\$40 billion more of private capital [124]. 
A realistic opportunity may exist now that some indices show companies conforming to ESG are outperforming other stocks, boosting the business case for investing accordingly [97]. What can MDBs do to involve private financiers? In each sub-section we sketch an answer based on what they have already done, then proceeding to a more speculative realm, through to the last section before the conclusion.

\subsubsection{Leveraging Their Unique Advantages to "De-Risk" Private Partners}

Scholars have argued for some time that indigenous or local knowledge is key to identification of risks [125]. Private financiers lack local or indigenous knowledge of developing (and even of developed) markets sufficient to winnow the bankable projects from the chaff. One pivotal service of MDBs is to use their local knowledge to lessen the risk of lending money. In theory, MDBs can de-risk in as many ways as there are kinds of risks. They do extensive high-quality preparation and implementation already (viz., due diligence; monitoring), and act to contain contingent liabilities arising from certain kinds of public-private partnerships [126]. De-risking devices like risk-guarantee and partial credit-guarantee instruments, bespoke to specific projects, may shield private partners from risks that would otherwise bar feasibility. MDB-structured investments generally reduce transaction costs, including that of due diligence, which can alone tip the balance from failure to success [71]. It should be noted that MDBs' willingness to assume risk is tempered by the imperative to keep up their credit rating $[4,106]$.

The World Bank Group's IFC is the pioneer in de-risking. Its innovations include: (1) Assuming some of the default risk: IFC's own equity and long-term debt instruments make a difference if local financial markets are weak or not attracting foreign direct investment. (2) Deploying its structuring and appraisal skills: IFC is a judicious appraiser with long experience in "rigging" sound projects in difficult environments. It is savvy to diverse business climates and knows how to secure local regulatory approvals. (3) Allaying by its participation the perception of risk: As an IGO, it provides assurances that can dampen subjective political risk, which is especially good for syndications. As Lender of Record, its political connections shelter its private partners, and this also lowers the borrowers' costs [127]. The World Bank too became a de-risking norm entrepreneur by founding the Multilateral Investment Guarantee Agency (MIGA) in 1988 to extend de-risking assurances to emerging markets [128]. As of June 2019, MIGA guarantees had grown 6\% over FY18 and had doubled FY15's number [129]. If MDBs were more proactive, they could be almost uniquely qualified to facilitate private participation in sustainable projects. Regional MDBs in particular bear potential to act as general clearing-houses for local private participation.

Local knowledge is indispensable to achieve the SDGs because project implementation happens or not at the national and the local levels in reality [130]. One must never lose sight of the end-goal of development: the local community benefit. If financing is informed by local knowledge, this sustains the be-all and end-all of development: those who are supposed to receive it. Researchers comparing the lifecycles of projects, and considering local versus "external" knowledge, found that those reliant upon external knowledge used a single tree/crop combination (for example), and were focused on return on investment; whereas, projects derived from local or mixed knowledge were oriented toward food security and formation of natural capital (soil restoration for example), using diversified trees and crops;- - considerations that foreign capital may be blissfully unaware of [131]. Integration of sources of knowledge better enabled locals to cope with climate change and volatile market prices and avoid destructive land use practices (for example, uncontrolled fires and aerial fumigation). Yet most projects tended to privilege external over local knowledge [131,132]. It is critical to understand the future risks in the locale served by the project; but finding locale-specific information is costly. Even the predictions of official tools can diverge widely from the impacts actually observed on the ground, especially after extreme events [133].

MDBs are increasingly working with national development banks (NDBs) that possess a hoard of unique local knowledge of great interest to sustainable banking, particularly connections to local 
markets and actors [134], and which can supply long-term financing in local currency. In September 2019 MDBs committed themselves to working further with national development banks to develop policies and strategies for a just transition to economic diversification [124] before the UN Framework Convention on Climate Change, twenty-sixth Conference of the Parties (COP26) held in Glasgow in 2020. The partnership between MDBs and NDBs could be the key to unlock the door to commercial finance at scale. MDB-NDB partnerships help elaborate common standards and principles, coordinate expertise, share risk, and pool financial resources for sustainable joint projects [135]. Although they can bring in capitalization that matches or exceeds that of MDBs, NDBs rarely participate in international projects, partly owing to significant barriers to foreign operations, from inability to affect delayed payments to lack of official status abroad. Partnering with MDBs bids fair to bypass these barriers, which in turn would unleash major financing advantages for MDBs and their private partners. NDBs can correct the inefficiencies of private capital markets, as by balancing its pro-cyclicality; promoting innovation and structural transformation; and enhancing inclusion by catering for the dynamic local SME (small and medium-sized enterprise) sector [136].

Collaboration with NDBs commends itself so expediently that MDBs like the AIIB, for example, will likely try it in the near future, despite not having so much as drafted the requisite formalities yet [135]. National governments will be prone to resist, possibly fiercely, any loss of dominion over their own national development banks. But the prospect is that, if only some successful MDB-NDB partnerships involving private capital could be established to incentivize domestic governments, it could precipitate a norm cascade that standardizes and normalizes how the latter govern NDBs. The attempt constitutes a Konstruktpolitik project the success of which hinges on MDBs' and other interested IGOs' competence to redirect the social construction of development finance. The great barrier is the impact of partisan swings of domestic politics on the NDBs, and on the MDBs that states are members of. For now, politics can complicate MDB-NDB collaboration. Konstruktpolitik's remit is precisely to simplify and rationalize this state of affairs, durably.

\subsubsection{Leading on Transparency and Guidance in Tracking Green Finance Flows}

As noted above, tracking capital flows in sustainable development is prohibitively dear for the commercial sector. MDBs have been the pioneers in innovating solutions for these issues on multiple fronts. We will review some of the advances that MDBs have made, that have been allowing commercial banks more and more feasible opportunities for bankable investments in green finance. The MDBs were ahead of the European Commission and its High-Level Expert Group (HLEG), to say nothing of the commercial banking industry, in pressing the issue of taxonomies. For instance, the HLEG recommendations [137] accepted by the European Commission in its 2019 EU Taxonomy Technical Report [94] were deeply influenced by the European Investment Bank (EIB) [60]. The HLEG was established in December 2016 to formulate a comprehensive strategy on sustainable finance that could be integrated into EU financial policy [138]. The EIB was invited in as an observer and in this capacity managed the elaboration of a classification of climate change mitigations, which the HLEG adopted [139]. Crucially, the EIB was able to draw on its experience in writing a joint White Paper with the Green Finance Committee of the China Society for Finance and Banking to support issuance of "green bonds" in China, which was released at the COP23 in 2017 [140].

The EIB is formulating a Rosetta Stone for green assets to facilitate interlocution between existing taxonomies, empowering every market stakeholder to compare every green asset to every other, thus helping mobilize capital flows into the most eligible assets. EIB plans to follow up with taxonomies for other sectors [138]. The European Union's taxonomies are useful to other parts of the world where the budget to develop them may not exist. MDBs also fund ESG research, the challenge and expense of producing quality in which scholars have long complained about [141]. This is another venture in Konstruktpolitik, if less chancy than normalizing MDB-NDB collaboration. 


\subsubsection{Innovating the Matchmaking of Commercial Banks with Sustainable Projects}

Green bonds. Harmonized reporting and sustainable taxonomies assure only that green projects are probably genuine; they do not assure bankability at all. Hence, the capacity of commercial banks to make matches between capital supply and demand remains limited. Although matchmaking mechanisms have lately begun to be elaborated, their scale remains too limited for 2030 purposes. The MDBs' experience contains lessons for scaling up. Green bonds are capital leveraging instruments pioneered by MDBs to attract private funds into sustainable investing. Investors in them span the gamut of established investment institutions [142]. As MDBs are solvent banks with high credit ratings, even central banks and public bodies hold their bonds, endowing them with the credibility to mobilize capital through green bonds as well. MDBs either issue the green bonds themselves, using the proceeds to finance projects, or else they bring credit enhancements to the table to enable private firms or projects to issue green corporate or project bonds backed by project tangibles. This is a long-term, cost-effective financing alternative [71].

The pioneer of green bonds in 2007 was the EIB with its Climate Awareness Bond, a "structured" bond dedicated to clean energy projects. MDBs (and like supranational agencies) were green bonds' only issuers before 2012 [143]. From 2010 to 2014 the EIB was the world's top green financier [60]. It remains the biggest lender of multilateral funds, mobilizing " 56.4 billion EUR from the international capital markets in 2017" [60] (p. 17). Global green bond issuance topped US $\$ 47$ billion in the first quarter of 2019, according to Moody's, but is expected to hit US\$200 billion by year's end, up from US $\$ 167$ billion in 2018 [144]. The EIB attracts investors who would not dare (or bother) to invest in European projects, yet are willing to chip-in out of confidence in the EIB itself [60]. A general solution to the problem of confidence is green mutual funds, the number of which has soared. As early as 2005 Europe had 300 such funds [145]. Presumably, they are making a profit if they are not bankrupt. But, however sustainable by Western norms, are they actually delivering the finance that the peoples of developing countries need, other than economic return (which admittedly they also need)? This unresolved issue still haunts norm entrepreneurs in the field of sustainable banking.

Blended finance. The idea of mobilizing private capital for sustainable projects has undergone successive transformations [146]. The prototype is the loan syndication. An MDB invites commercial banks to co-finance projects through an A/B loan: private financiers give the $\mathrm{B}$ loan, while the MDB lends the A share from its own capital, being also the Lender of Record, Lead Lender, and Administrative Agent for the facility. It assumes some major financial risks and costs of private partners, "catalyzing" a transaction otherwise infeasible [147]. MDBs have been making arrangements like this for decades. Experience shows that PPPs, instead of evenly distributing funds, cluster it in the strongest or "emerging" markets, in low-risk sectors; disappointing the expectations of low-income countries. Given that syndication loans are often the dearest; are complex to negotiate and implement, driving transaction costs higher than public works; are risky for the public fisc; are incompetent at reducing poverty, inequality and environmental damage; and lacking in transparency to the detriment of democratic accountability [148], it might be best to embed private sector mobilization in vehicles that simultaneously mobilize the public sector [149]. Blended finance is one version of this idea.

Blended finance uses easily repayable, offsetting concessional funds, typically provided by MDBs, to de-risk private funds, in tandem with other instrumentalities furnished by MDBs like non-recourse project financing, risk mitigation instruments, and pooled funding structures [150]. Blended finance was cited as critical to mobilizing capital at the Third International Conference on Financing for Development in Addis Ababa in 2015 [151]. There too the Convergence facility was set up as a matchmaking platform, and to subsidize innovations in blended finance. MDBs have pioneered integrating blended finance into the services offered to developing countries: The World Bank Group's "cascade approach" prioritizes commercial capital, whilst also helping to reform the local investment climate and right market failures behind the scenes [151].

The Business and Sustainable Development Commission (BSDC), set up at Davos in January 2016 on the sidelines of the World Economic Forum, found that blended financing had mobilized 
US\$51.2 billion through July 2017 [152]. BSDC commissioned the Blended Finance Taskforce in 2017 to inquire how else development aid might be leveraged to raise more private capital [153]. MDBs' current private-to-public capital ratios are less than 1:1 across their portfolios. The private quotient needs to more than double in the next decade to even approach a trillion dollars [153]. This is doable: A recent study estimated that $\$ 12$ trillion of market opportunities could be unlocked and 380 million new jobs created by 2030 [75]. MDBs' catalytic role is to "crowd-in" private investors, while helping mobilize local resources supplementally [154]. Here it is less clear how to effect change. The options of MDBs are constrained by the intergovernmental politics that go on inside multilateral organizations, along with the low leverage so far achieved by public-private syndications. This is a fit topic for future research into the ways and means of Konstruktpolitik.

\section{Conclusions}

MDBs have proven to be the key catalyst in the evolution of sustainable banking practices and norms. Since the 1970s up to the present day, the "entrepreneurial hegemons" among the MDBs (viz., the World Bank Group, the EBRD, and the EIB) have pioneered a great deal of the actually workable sustainable finance mechanisms capable of de-risking and otherwise mobilizing the participation of commercial banks and other sources of private capital to achieve the development goals "legislated" by the UN and other IGOs. This they have accomplished by utilizing their own institutional strengths-especially sources of soft power such as their prestige, finance expertise, the exactitude and quality of their due diligence, and institutional incentives such as loan conditionality, - to convince "enough" stakeholders, private international finance above all, that their own norms of practice are universally applicable, objective standards of sustainable finance.

It was found that MDBs have been leveraging these advantages plus their deep local knowledge, or access thereto, to give more certainty and bankability to green projects by "de-risking" private financial partners, as well as through arrangements like: (1) Assuming some of the default risk if local financial markets are weak or not attractive, (2) deploying its structuring and appraisal skills from long experience with projects in difficult environments, and (3) allaying the perception of risk by its very participation. MDBs have enhanced transparency in tracking climate-finance flows, providing guidance to the private sector through pioneering the taxonomization of business activities according to their sustainability, and trying to create interoperability between already existing taxonomies. MDBs have, finally, taken the lead in trying to make matches between commercial banks and green projects; e.g., by pioneering green bonds, and by creating and elaborating "blended finance" or the leveraging of MDBs' own funds to "crowd in" (that is, alter the incentives of) commercial banks so that participation in sustainable projects is made more feasible.

This evolution of sustainable finance by the MDBs, however, is still "under construction". MDBs have much work to do before any credible prospect of achieving the sustainable development goals by 2030 (or ever) is in sight. It is suggested that understanding the precepts of constructivism could help organizations like MDBs and IGOs to socially construct urgently needed new norms in the clear knowledge of what is necessary at a minimum to make them "stick". A critical first step is simply to have more clarity about the importance of entrepreneurship as such in what MDBs are already doing. This is a strategic consideration that can spill over to the operational level. The key is to be aware of constructing self-fulfilling (or, as the case may be, self-negating) beliefs and expectations. Inquiry into the basis of such beliefs, social trust, and its creation and stabilization will pay dividends. MDBs should concentrate on bringing whatever is necessary (within reason) to bear on unlocking the vast reservoir of world savings, utilizing the soft power of a "new normal" to accommodate its limitations, especially its sensitivity to risk, to bring it into the sustainable banking equation in a massive way.

Author Contributions: All co-authors have contributed to this article as follows: conceptualization, A.M. and D.P.H.; methodology, A.M. and D.P.H.; validation, A.M. and D.P.H.; investigation, A.M. and D.P.H.; writing-original draft preparation, A.M. and D.P.H.; writing—review and editing. All authors have read and agreed to the published version of the manuscript. 
Funding: This research received no external funding.

Conflicts of Interest: The authors declare no conflict of interest.

\section{References}

1. UNCTAD TRADE AND DEVELOPMENT REPORT 2019: FINANCING A GLOBAL GREEN NEW DEAL. In Proceedings of the United Nations Conference on Trade and Development, New York, NY, USA, 25 September 2019; Available online: https://unctad.org/en/PublicationsLibrary/tdr2019_en.pdf (accessed on 22 January 2020).

2. UNCTAD. WORLD INVESTMENT REPORT: Investing in the SDGs-An Action Plan. In Proceedings of the United Nations Conference on Trade and Development, 24 June 2014; Available online: https: //unctad.org/en/PublicationChapters/wir2014ch4_en.pdf (accessed on 22 January 2020).

3. AfDB; ADB; EBRD; EIB; IDB; IMF; World Bank. From Billions to Trillions: Transforming Development Finance Post-2015 Financing for Development: Multilateral Development Finance; 2015; Available online: http: //pubdocs.worldbank.org/en/622841485963735448/DC2015-0002-E-FinancingforDevelopment.pdf (accessed on 22 January 2020).

4. Attridge, S.; Engen, L. Blended Finance in the Poorest Countries: The Need for a Better Approach; Overseas Development Institute (ODI): London, UK, 2019.

5. World Bank Gross domestic savings (current US\$): World 2018. Available online: https:/data.worldbank. org/indicator/NY.GDS.TOTL.CD (accessed on 28 December 2019).

6. ICESDF. Report of the Intergovernmental Committee of Experts on Sustainable Development Financing; United Nations: New York, NY, USA, 2014.

7. Mawdsley, E. 'From billions to trillions': Financing the SDGs in a world 'beyond aid'. Dialogues Hum. Geogr. 2018, 8, 191-195. [CrossRef]

8. Alden, C.; Large, D.; Mendez, A. The Western Way of Development: A Critical Review. In New Development Assistance: Emerging Economies and the New Landscape of Development Assistance; Jing, Y., Mendez, A., Zheng, Y., Eds.; Palgrave Macmillan: Basingstoke, UK, 2020; pp. 19-38.

9. Jing, Y.; Mendez, A.; Zheng, Y. New Development Assistance in the Making: An Introduction. In New Development Assistance: Emerging Economies and the New Landscape of Development Assistance; Jing, Y., Mendez, A., Zheng, Y., Eds.; Palgrave Macmillan: Basingstoke, UK, 2020; pp. 1-18.

10. Farias, C.; Fernandez, P.; Hjorth, D.; Holt, R. Organizational entrepreneurship, politics and the political. Entrep. Reg. Dev. 2019, 31, 555-566. [CrossRef]

11. Weber, O.; Feltmate, B. Sustainable Banking: Managing the Social and Environmental Impact of Financial Institutions; University of Toronto Press: Toronto, ON, Canada, 2016.

12. Forcadell, F.J.; Aracil, E. Sustainable banking in Latin American developing countries: Leading to (mutual) prosperity. Bus. Ethics: Eur. Rev. 2017, 26, 382-395. [CrossRef]

13. Bouma, J.J.; Jeucken, M.; Klinkers, L. Sustainable Banking: The Greening of Finance; Greenleaf Publishing Limited: Sheffield, UK, 2001.

14. Delikanli, I.U.; Dimitrov, T.; Agolli, R. Multilateral Development Banks: Governance and Finance; Springer International Publishing: Cham, Switzerland, 2018.

15. Gutner, T.L. Banking on the Environment: Multilateral Development Banks and their Environmental Performance in Central and Eastern Europe; MIT Press: Cambridge, MA, USA, 2002.

16. Nelson, R. Multilateral Development Banks: Overview and Issues for Congress; R41170; Congressional Research Service (CRS): Washington, DC, USA, 6 July 2018; Available online: https://fas.org/sgp/crs/row/R41170.pdf (accessed on 22 January 2020).

17. Kellerman, M. The proliferation of multilateral development banks. Rev. Int. Organ. 2019, 14, 107-145. [CrossRef]

18. Finnemore, M.; Sikkink, K. International norm dynamics and political change. Int. Organ. 1998, 52, 887-917. [CrossRef]

19. Sunstein, C.R. Social Norms and Social Roles. Columbia Law Rev. 1996, 96, 903-968. [CrossRef]

20. Nadelmann, E.A. Global prohibition regimes: the evolution of norms in international society. Int. Organ. 1990, 44, 479-526. [CrossRef]

21. Finnemore, M. National Interests In International Society; Cornell University Press: Ithaca, NY, USA, 1996. 
22. Dominguez, J.I. International cooperation in Latin America: the design of regional institutions by slow accretion. In Crafting Cooperation: Regional International Institutions in Comparative Perspective; Acharya, A., Johnston, A.I., Eds.; Cambridge University Press: Cambridge, UK, 2007; pp. 83-128.

23. Hamilton, D.S. The United States: A Normative Power. In Who is a Normative Foreign Policy Actor?: The European Union and Its Global Partners; Tocci, N., Ed.; Centre for European Policy Studies: Brussels, Belgium, 2008; pp. 76-155.

24. Lessig, L. The Regulation of Social Meaning. U. Chi. L. Rev. 1995, 62, 968-973. [CrossRef]

25. Wendt, A. Anarchy is what States Make of it: The Social Construction of Power Politics. Int. Organ. 1992, 46, 391-425. [CrossRef]

26. Houghton, D.P. Reinvigorating the Study of Foreign Policy Decision Making: Toward a Constructivist Approach. Foreign Policy Anal. 2007, 3, 24-45. [CrossRef]

27. Houghton, D.P. Constructivist Analyses of Foreign Policy. In Oxford Research Encyclopedia of Foreign Policy; Thies, C., Ed.; Oxford University Press: New York, NY, USA, 2018; Volume 1, pp. 223-240.

28. Mendez, A. Colombian Agency and the Making of US Foreign Policy: Intervention by Invitation; Routledge: Abingdon, UK, 2017.

29. Huntington, S.P. The Clash of Civilizations and the Remaking of World Order; Simon \& Schuster: New York, NY, USA, 1996.

30. Houghton, D.P. The Role of Self-Fulfilling and Self-Negating Prophecies in International Relations. Int. Stud. Rev. 2009, 11, 552-584. [CrossRef]

31. Komori, Y. The Asian Development Bank: Joining the fight against corruption. In Global Economic Governance and the Development Practices of the Multilateral Development Banks; Park, S., Strand, J.R., Eds.; Routledge: Abingdon, UK, 2016; pp. 21-38.

32. Mendez, A. Global Governance in Foreign Policy. In The Oxford Encyclopedia of Foreign Policy Analysis; Thies, C.G., Ed.; Oxford University Press: New York, NY, USA, 2018; Volume 1, pp. 793-816.

33. Vogler, J. Environmental Issues. In The Globalization of World Politics: An Introduction to International Relations, 6th ed.; Baylis, J., Smith, S., Owens, P., Eds.; Oxford University Press: Oxford, UK, 2014; pp. 341-356.

34. Harrington, J.C. The Challenge to Power: Money, Investing, and Democracy; Chelsea Green Publishing Company: White River Junction, VT, USA, 2005.

35. Blowfield, M.; Murray, A. Corporate Responsibility, 2nd ed.; Oxford University Press: Oxford, UK, 2011.

36. Blowfield, M.; Dolan, C.S. Business as a development agent: evidence of possibility and improbability. Third World Q. 2014, 35, 22-42. [CrossRef]

37. Jones, G. Profits and Sustainability: A History of Green Entrepreneurship; Oxford University Press: Oxford, UK, 2017.

38. Brandt, W. North-South: A Programme for Survival (The Report of the Independent Commission on International Development Issues); Pan Books Ltd.: London, UK, 1980.

39. ODI. The Brandt Comission. In ODI Briefing Paper; Overseas Development Intitute: London, UK, 1980; Volume March, Available online: https://www.odi.org/publications/5378-brandt-commission-report (accessed on 22 January 2020).

40. World Commission on Environment and Development. Our Common Future (Brundtland Report); Oxford University Press: Oxford, UK, 1987.

41. Hens, L.; Nath, B. The World Summit on Sustainable Development: The Johannesburg Conference; Springer: Dordrecht, The Netherlands, 2005.

42. Lafferty, W.M. The politics of sustainable development: Global norms for national implementation. Environ. Polit. 1996, 5, 185-208. [CrossRef]

43. Seghezzo, L. The five dimensions of sustainability. Environ. Politics 2009, 18, 539-556. [CrossRef]

44. GEF. Financing Adaptation Action: Least Developed Countries Fund Special Climate Change Fund; Global Environment Facility: Washington, DC, USA, 2012.

45. From 1992 to 2019: The Evolution of Sustainable Finance, UNEP FI. Available online: https://www.unepfi. org/news/25th-anniversary/timeline/ (accessed on 27 December 2019).

46. Grubb, M. The "Earth Summit" Agreements: A Guide and Assessment, an Analysis of the Rio '92 UN Conference on Environment and Development; Earthscan Publications Ltd.: London, UK, 1993.

47. Schmidheiny, S.; Zorraquin, F. Financing Change: The Financial Community, Eco-efficiency, and Sustainable Development; MIT Press: Cambridge, MA, USA, 1996. 
48. Hák, T.; Moldan, B.; Dahl, A.L. Sustainability Indicators: A Scientific Assessment; Island Press: Washington, DC, USA, 2012.

49. UN. United Nations Millennium Declaration. In Resolution adopted by the General Assembly on 8 September 2000; United Nations: New York, NY, USA, 2000.

50. UN. Road map towards the implementation of the United Nations Millennium Declaration. In Report of the Secretary-General; United Nations: New York, NY, USA, 2001.

51. Vandemoortele, J. The MDG Story: Intention Denied. Dev. Change 2011, 42, 1-21. [CrossRef]

52. Sachs, J. The End of Poverty: How We can Make it Happen in Our Lifetime; Penguin: London, UK, 2005.

53. Victor, D.G. Recovering Sustainable Development. Foreign Aff. 2006, 85, 91-103. [CrossRef]

54. Evans, A.; Steven, D. What Happens Now? Time to Deliver the Post-2015 Development Agenda; CIC at New York University: New York, USA, 2015; Available online: https:/cic.nyu.edu/sites/default/files/what_happens_ now_post2015_1.pdf (accessed on 22 January 2020).

55. UN. Transforming our world: the 2030 Agenda for Sustainable Development. In Resolution adopted by the General Assembly on 25 September 2015; United Nations: New York, NY, USA, 2015.

56. Kates, R.W.; Parris, T.M.; Leiserowitz, A.A. What is Sustainable Development? Goals, Indicators, Values, and Practice. Environ. Sci. Policy Sustain. Dev. 2005, 47, 8-21.

57. National Academy of Sciences. Our Common Journey: A Transition Toward Sustainability; National Academy Press: Washington, DC, USA, 1999.

58. Weber, O. Environmental Credit Risk Management in Banks and Financial Service Institutions. Bus. Strat. Env. 2012, 21, 248-263. [CrossRef]

59. Forcadell, F.J.; Aracil, E. European Banks' Reputation for Corporate Social Responsibility. Corp. Soc. Responsib. Environ. Mgmt. 2017, 24, 1-14. [CrossRef]

60. Țîrcă, D.-M.; Apetri, A.-N.; Aceleanu, M. Sustainability in Finance and Economics. In Financing Sustainable Development: Key Challenges and Prospects; Ziolo, M., Sergi, B.S., Eds.; Palgrave Macmillan: Cham, Switzerland, 2019; pp. 9-52.

61. Elkington, J. Towards the Sustainable Corporation: Win-Win-Win Business Strategies for Sustainable Development. Calif. Manag. Rev. 1994, 36, 90-100. [CrossRef]

62. UN. The Millennium Development Goals Report 2015; United Nations: New York, NY, USA, 2015.

63. MacDonald, A.; Clarke, A.; Huang, L.; Roseland, M.; Seitanidi, M.M. Multi-stakeholder Partnerships (SDG \#17) as a Means of Achieving Sustainable Communities and Cities (SDG \#11). In Handbook of Sustainability Science and Research; Leal Filho, W., Ed.; Springer: Cham, Switzerland, 2018; pp. 193-209.

64. Elkington, J. 25 Years Ago I Coined the Phrase "Triple Bottom Line." Here's Why It's Time to Rethink It. Harv. Bus. Rev. 2018. Available online: https://store.hbr.org/product/25-years-ago-i-coined-the-phrasetriple-bottom-line-here-s-why-it-s-time-to-rethink-it/H04E7P (accessed on 22 January 2020).

65. Sridhar, K.; Jones, G. The three fundamental criticisms of the Triple Bottom Line approach: An empirical study to link sustainability reports in companies based in the Asia-Pacific region and TBL shortcomings. Asian J. Bus. Ethics 2013, 2, 91-111. [CrossRef]

66. Zhu, L.; Chua, D.K.H. Identifying Critical Bankability Criteria for PPP Projects: The Case of China. Adv. Civ. Eng. 2018, 2018, 1-11. [CrossRef]

67. Cooper, P.J.; Vargas, C.M. Implementing Sustainable Development: From Global Policy to Local Action; Rowman \& Littlefield Publishers: Boulder, CO, USA, 2004.

68. Caplen, B. Making money move South. In The Banker; Financial Times Ltd.: London, UK, 2019.

69. Finnerty, J.D. Project Financing: Asset-Based Financial Engineering; John Wiley \& Sons: Hoboken, NJ, USA, 2007.

70. Jacobsen, M. Project Costing and Financing. In Water and Wastewater Management in the Tropics; Lonholdt, J., Ed.; IWA Publishing: Padstow, UK, 2005; pp. 50-120.

71. Mo, L. Effective Private Financing Approaches and Equity Financial Instruments for Low-Carbon Energy Investment: ADB Experiences. In Financing for Low-carbon Energy Transition: Unlocking the Potential of Private Capital; Anbumozhi, V., Kalirajan, K., Kimura, F., Eds.; Springer: Singapore, 2018; pp. 277-316.

72. Kaminker, C.; Stewart, F. The Role of Institutional Investors in Financing Clean Energy; OECD: Paris, France, 2012.

73. Howarth, N. Clean Energy Technology and the Role of Non-Carbon Price-Based Policy: An Evolutionary Economics Perspective. Eur. Plann. Stud. 2012, 20, 871-891. [CrossRef]

74. Mashamba, T. The effects of Basel III liquidity regulations on banks' profitability. J. Gov. Regul. 2018, 7, 34-48. [CrossRef] 
75. BSDC. Better Business Better World: The report of the Business \& Sustainable Development Commission; Business and Sustainable Development Commission: London, UK, 2017.

76. Ernst \& Young, Why Sustainable Development Goals should be in your business plan. Available online: https://www.ey.com/en_gl/assurance/why-sustainable-development-goals-should-be-in-yourbusiness-plan (accessed on 22 January 2020).

77. Pavoni, S. How green is your bank? Defining sustainable finance. In The Banker; The Financial Times Ltd.: London, UK, 2019.

78. GRI Global Reporting Initiative. Available online: https://www.globalreporting.org/Information/about-gri/ Pages/default.aspx (accessed on 16 November 2019).

79. Tett, G.; Nauman, B.; Temple-West, P. Moral Money: infighting undermines ESG standarisation push. Financial Times, 13 November 2019; Pagination. Available online: https://www.ft.com/content/0b354b76-059e11ea-a984-fbbacad9e7dd(accessed on 22 January 2020).

80. Crow, D.; Binham, C. Banks pushed to cleanse their balance sheets of climate risk. Financial Times, 26 December 2018; Pagination. Available online: https://www.ft.com/content/e697d3bc-ff98-11e8-ac0057a2a826423e(accessed on 22 January 2020).

81. Rezaee, Z.; Fogarty, T. Business Sustainability, Corporate Governance, and Organizational Ethics; Wiley: Hoboken, NJ, USA, 2019.

82. Crow, D. Third of biggest banks fail to sign up to climate initiative. Financial Times, 15 October 2019. Available online: https://www.ft.com/content/0eec5a1e-ee99-11e9-ad1e-4367d8281195(accessed on 22 January 2020).

83. Forcadell, F.J.; Aracil, E.; Úbeda, F. The Influence of Innovation on Corporate Sustainability in the International Banking Industry. Sustainability 2019, 11, 3210. [CrossRef]

84. Fontaine, H.; Abbam, M.; Zia, H.; Hoell, J.; Plant, A. Task Force on Climate-related Financial Disclosures (TCFD) Recommendations: Global Progress Report for the Banking Sector; BCS Consulting: London, UK, 2019; Available online: https://www.bcsconsulting.com/wp-content/uploads/2019/11/043_Global-Process-ReportDocument_Final_small.pdf (accessed on 22 January 2020).

85. Baraldi, D. Banking on sustainability-what's next. In Sustainable Development Impact Summit; World Economic Forum: Davos, Switzerland, 2019.

86. Carney, M. TCFD: strengthening the foundations of sustainable finance. In Proceedings of the TCFD Summit 2019, Tokyo, Japan, 8 October 2019; Available online: https://www.bis.org/review/r191008a.pdf (accessed on 22 January 2020).

87. ClientEarth. Risk Unwrapped: Plastic Pollution as a Material Business Risk; ClientEarth: London, UK, 2018; Available online: https://www.documents.clientearth.org/wp-content/uploads/library/2018-07-24-riskunwrapped-plastic-pollution-as-a-material-business-risk-ce-en.pdf (accessed on 22 January 2020).

88. Rich, P. The Organizational Taxonomy: Definition and Design. Acad. Manag. Rev. 1992, 17, 758-781. [CrossRef]

89. Planty, M.; Carlson, D. Understanding Education Indicators: A Practical Primer for Research and Policy; Teachers College Press: New York, NY, USA, 2015.

90. Olsen, K.H.; Fenhann, J. Sustainable development benefits of clean development mechanism projects: A new methodology for sustainability assessment based on text analysis of the project design documents submitted for validation. Energy Policy 2008, 36, 2819-2830. [CrossRef]

91. Franklin, J. Banks cautiously optimistic about EU's sustainability framework. In International Financial Law Review; IFLR: London, UK, 2019.

92. NGFS. A Call for Action Climate Change as a Source of Financial Risk; Network for Greening the Financial System: London, UK, 2019.

93. EU taxonomy for sustainable activities, European Commission. Available online: https://ec.europa.eu/info/ publications/sustainable-finance-teg-taxonomy_en (accessed on 21 October 2019).

94. European Commission. EU Taxonomy Technical Report; Technical Expert Group of Sustainable Finance: Brussels, Belgium, 18 June 2019.

95. UNEP FI. Principles for Responsible Banking; United Nations Environmental Programme-Finance Initiative: Geneva, Switzerland, 2019; Available online: https:/www.unepfi.org/wordpress/wp-content/uploads/2019/ 09/PRB-Guidance-Document-Final-19092019.pdf (accessed on 22 January 2020).

96. ITC. SME Competitiveness Outlook 2019: Big Money for Small Business - Financing the Sustainable Development Goals; International Trade Centre: Geneva, Switzerland, 2019. 
97. Edgecliffe-Johnson, A. Global business chiefs pledge to boost sustainable development. Financial Times, 16 October 2019. Available online: https://www.ft.com/content/15ae565a-efc4-11e9-ad1e4367d8281195(accessed on 22 January 2020).

98. Cordon, R. International matchmaking and business partnering. Int. Trade Forum 2001, $29-31$.

99. Lemma, A.F.; Ellis, K. Centrally Managed Donor Funds and facilities To Promote Business Engagement; Overseas Development Institute: London, UK, 2014.

100. Taghizadeh-Hesary, F.; Yoshino, N. The way to induce private participation in green finance and investment. Finance. Res. Lett. 2019, 31, 98-103. [CrossRef]

101. De Broeck, W. Crowdfunding platforms for renewable energy investments: anoverview of best practices in the EU. Int. J. Sustain. Energy Plan. Manag. 2018, 15, 3-10.

102. Natixis GREEN \& SUSTAINABLE HUB. Available online: https://gsh.cib.natixis.com/ (accessed on 30 October 2019).

103. HM Government. Green Finance Strategy: Transforming Finance for a Greater Future; UK Government: London, UK, 2019.

104. Guterres, A. Progress toward sustainable development is seriously off-track. Financial Times, 4 November 2019; Pagination. Available online: https://www.ft.com/content/0c0eadc6-f739-11e9-bbe1-4db3476c5ff0(accessed on 22 January 2020).

105. UN. Global Investors for Sustainable Development Alliance. 2019. Available online: https://www.un.org/esa/ffd/ wp-content/uploads/2019/10/GISD-1015.pdf (accessed on 22 January 2020).

106. Humphrey, C. He who pays the piper calls the tune: Credit rating agencies and multilateral development banks. Rev. Int. Organ. 2017, 12, 281-306. [CrossRef]

107. Bhattacharya, A.; Kharas, H.; Plant, M.; Prizzon, A. The New Global Agenda and the Future of the Multilateral Development Bank System. Int. Organ. Res. J. 2018, 13, 101-124. [CrossRef]

108. Prizzon, A. Introduction and Overview. In Six Recommendations for Reforming Multilateral Development Banks: An Essay Series; ODI, Ed.; Overseas Development Institute: London, UK, 2017; pp. 6-9.

109. Prizzon, A.; Humphrey, C.; Kaul, I.; Kodera, K.; McKechnie, A.; Rogerson, A. Six Recommendations for Reforming Multilateral Development Banks: An Essay Series; ODI, Ed.; Overseas Development Institute: London, UK, 2017.

110. Ahluwalia, M.S.; Summers, L.; Velasco, A.; Birdsall, N.; Morris, S. Banking for this Century's Development Challenges: Five Recommendations to Shareholders of the Old and New Multilateral Development Banks; Center for Global Development: Washington, DC, USA, 2016.

111. Langer, M.J. Key Instrument of private environmental finance: funds, project finance and market mechanisms. In Harnessing Foreign Investment to Promote Environmental Protection: Incentives and Safeguards; Dupuy, P.-M., Viñuales, J.E., Eds.; Cambridge University Press: Cambridge, UK, 2013; pp. 131-175.

112. Vives, A. The Role of Multilateral Development Institutions in Fostering Corporate Social Responsibility. Development 2004, 47, 45-52. [CrossRef]

113. Baumast, A. Equator Principles. In Encyclopedia of Corporate Social Responsibility; Idowu, S.O., Capaldi, N., Zu, L., Gupta, A.D., Eds.; Springer: Berlin/Heidelberg, Germany, 2013; pp. 1045-1051.

114. The Equator Principles, EP. Available online: https://equator-principles.com/about/ (accessed on 28 December 2019).

115. McIntyre, O. Development Banking ESG Policies and the Normativisation of Good Governance Standards: Development Banks as Agents of Global Administrative Law. In Responsible Investment Banking: Risk Management Frameworks, Sustainable Financial Innovation and Softlaw Standards; Wendt, K., Ed.; Springer International Publishing: Cham, Switzerland, 2015; pp. 143-155.

116. Broccolini, C.; Lotti, G.; Maffioli, A.; Presbitero, A.F.; Stucchi, R. Mobilization Effects of Multilateral Development Banks. IMF Working Paper 2019. [CrossRef]

117. Chin, G.T. The Asian Infrastructure Investment Bank-New Multilateralism: Early Development, Innovation, and Future Agendas. Glob. Policy 2019, 10, 569-581. [CrossRef]

118. Vazquez, K.C.; Chin, G.T. The AIIB and Sustainable Infrastructure: A Hybrid Layered Approach. Glob. Policy 2019, 10, 593-603. [CrossRef]

119. Mendez, A.; Turzi, M. The Political Economy of China-Latin America Relations: The AIIB Membership; Palgrave Pivot (in-print): New York, NY, USA, 2020. 
120. Mendez, A.; Alden, C. China in Panama: From Peripheral Diplomacy to Grand Strategy. Geopolitics 2019, 1-23. [CrossRef]

121. Mendez, A. Latin America and the AIIB: Interests and Viewpoints. Glob. Policy 2019, 10, 639-644. [CrossRef]

122. Mohieldin, M.; Verbeek, J.; Subramaniam, N. Crowding-In Private Finance: What Multilateral Development Banks Can Do Differently. In From Summits to Solutions: Innovations in Implementing the Sustainable Development Goals; Desai, R.M., Katō, H., Kharas, H.J., Eds.; Brookings Institution Press: Washington, DC, USA, 2018; pp. 353-370.

123. Merritt, A.; Stubbs, T. COMPLEMENTING THE LOCAL AND GLOBAL: PROMOTING SUSTAINABILITY ACTION THROUGH LINKED LOCAL-LEVEL AND FORMAL SUSTAINABILITY FUNDING MECHANISMS. Publ. Admin. Dev. 2012, 32, 278. [CrossRef]

124. ADB; AFDB; AIIB; EBRD; EIB; IDB; ISDB; NDB; World Bank. High Level MDB Statement. Available online: https://www.aiib.org/en/news-events/news/2019/_download/Joint-MDB-statement-onclimate-change-finance-FINAL-220919.pdf (accessed on 24 December 2019).

125. Senanayake, S.G.J.N. Indigenous knowledge as a key to sustainable development. J. Agric. Sci. 2006, 2, 87-94. [CrossRef]

126. Mohieldin, M.; Subramaniam, N.; Verbeek, J. Multilateral Development Banks must mobilize private finance to achieve the SDGs. In The Brookings Institution; 2018; Available online: https://www.brookings.edu/blog/ up-front/2018/07/19/multilateral-development-banks-must-mobilize-private-finance-to-achieve-the-sdgs/ (accessed on 22 January 2020).

127. IFC. Project Finance in Developing Countries; International Finance Corporation: Washington, DC, USA, 1999.

128. Perkal, D. Multilaterals develop a new side. Infrastruct. Financ. 1996, 5, 46-49.

129. MIGA. 2019 Annual Report; Multilateral Investment Guarantee Agency (MIGA)-World Bank Group: Washington, DC, USA, 2019.

130. Stafford-Smith, M.; Griggs, D.; Gaffney, O.; Ullah, F.; Reyers, B.; Kanie, N.; Stigson, B.; Shrivastava, P.; Leach, M.; O'Connell, D. Integration: the key to implementing the Sustainable Development Goals. Sustain. Sci. 2017, 12, 911-919. [CrossRef] [PubMed]

131. Jacobi, J.; Mathez-Stiefel, S.-L.; Gambon, H.; Rist, S.; Altieri, M. Whose Knowledge, Whose Development? Use and Role of Local and External Knowledge in Agroforestry Projects in Bolivia. Environ. Manag. 2017, 59, 464-476. [CrossRef] [PubMed]

132. Hoch, L.; Pokorny, B.; Jong, W. Financial attractiveness of smallholder tree plantations in the Amazon: bridging external expectations and local realities. Agroforest. Syst. 2012, 84, 361-375. [CrossRef]

133. Coffee, J. Financing Resilient Infrastructure. In Optimizing Community Infrastructure; Colker, R., Ed.; Butterworth-Heinemann: Oxford, UK, 2020; pp. 101-121.

134. Smallridge, D.; Buchner, B.; Trabacchi, C.; Netto, M.; Gomes Lorenzo, J.J.; Serra, L. The Role of National Development Banks in Catalyzing International Climate Finance; Inter-American Development Bank: Washington, DC, USA, 2013.

135. Shelepov, A.V. The AIIB, multilateral and national development banks: potential for cooperation. Vestnik RUDN. Int. Relat. 2018, 18, 135-147. [CrossRef]

136. Griffith-Jones, S.; Ocampo, J.A.; Rezende, F.; Schclarek, A.; Brei, M. The Future of National Development Banks. In The Future of National Development Banks; Griffith-Jones, S., Ocampo, J.A., Eds.; Oxford University Press: Oxford, UK, 2018; pp. 1-38.

137. European Commission. FINANCING A SUSTAINABLE EUROPEAN ECONOMY: Final Report; EU High-Level Expert Group on Sustainable Finance: Brussels, Belgium, 2018; Available online: https://ec.europa. eu/transparency/regexpert/index.cfm?do=groupDetail.groupDetailDoc\&id=36814\&no=1 (accessed on 22 January 2020).

138. EIB Climate Awareness Bonds: Newsletter H1 2017. Available online: https://www.eib.org/attachments/fi/ 2017-H1-cab-newsletter.pdf (accessed on 22 December 2019).

139. EIB Climate Awareness Bonds - Newsletter March 2018. Available online: https://www.eib.org/attachments/ fi/2017-cab-newsletter-en.PDF (accessed on 21 December 2019).

140. EIB; GFC. The need for a common language in Green Finance: Towards a Standard-neutral Taxonomy for the Environmental Use of Proceeds; European Investment Bank and Green Finance Committee of China Society for Finance and Banking: Luxembourg, 2017. 
141. Carmody, L.; Dodge, L. Mitigating ESG Risk in Asian Portfolios. In Evolutions in Sustainable Investing: Strategies, Funds and Thought Leadership; Krosinsky, C., Robins, N., Viederman, S., Eds.; John Wiley \& Sons: Hoboken, NJ, USA, 2011; pp. 313-322.

142. Anbumozhi, V.; Timilsina, P. Leveraging Private Finance Through Public Finance: Role of International Financial Institutions. In Financing for Low-carbon Energy Transition: Unlocking the Potential of Private Capital; Anbumozhi, V., Kalirajan, K., Kimura, F., Eds.; Springer: Singapore, 2018; pp. 317-334.

143. Ketterer, J.A.; Andrade, G.; Netto, M.; Haro, M.I. Transforming Green Bond Markets: Using Financial Innovation and Technology to Expand Green Bond Issuance in Latin America and the Caribbean; Inter-American Development Bank: Washington, DC, USA, 2019.

144. Asgari, N. World's top pension fund warns against risk of green-bond 'fad'. Financial Times, 3 July 2019; Pagination. Available online: https://www.ft.com/content/f844f1c2-998e-11e9-8cfb-30c211dcd229(accessed on 22 January 2020).

145. Koellner, T.; Weber, O.; Fenchel, M.; Scholz, R. Principles for Sustainability Rating of Investment Funds. Bus. Strat. Environ. 2005, 14, 54-70. [CrossRef]

146. Pekmezovic, A. Re-Orienting the Global Financial System Towards Sustainability. In Sustainable Development Goals: Harnessing Business to Achieve the SDGs through Finance, Technology and Law Reform; Walker, J., Pekmezovic, A., Walker, G., Eds.; Wiley: Chichester, UK, 2019; pp. 121-142.

147. IDB: A/B Loans and Syndications. Available online: https://www.iadb.org/en/about-us/ab-loans-andsyndications (accessed on 11 November 2019).

148. Romero, M.J. What Lies Beneath? A Critical Assessment of PPPs and Their Impact on Sustainable Development; European Network on Debt and Development: Brussels, Belgium, 2015.

149. Jacobs, B. Can the Addis Ababa Action Agenda Bring about a More Integrated Blend? Facilitating African Infrastructure Development Through Institutionalized Portfolio Approaches. Forum Dev. Stud. 2016, 43, 385-413. [CrossRef]

150. UN. Addis Ababa Action Agenda: Monitoring Commitments and Actions (Innaugural Report 2016); Inter-agency Task Force on Financing for Development, United Nations: New York, NY, USA, 2016.

151. OECD. The State of Blended Finance 2018; OECD Publishing: Paris, France, 2018.

152. BSDC. THE STATE OF BLENDED FINANCE; Working Paper; Business \& Sustainable Development Commission: London, UK, 2017.

153. BSDC. BETTER FINANCE BETTER WORLD: Consultation Paper of the Blended Finance Taskforce; Business \& Sustainable Development Commission: London, UK, 2018.

154. Bhattacharya, A.; Oppenheim, J.; Stern, N. Driving Sustainable Development through Better Infrastructure: Key Elements of a Transformation Program. In Global Economy and Development at Brookings; The Brookings Institution: Washington, DC, USA, 2015. 